\title{
Total RNA Expression Profile
}

National Cancer Institute

\section{Source}

National Cancer Institute. Total RNA Expression Profile. NCI Thesaurus. Code C129766.

An analysis of all of the RNA molecules expressed in a biological sample. 